\title{
Faktor-Faktor Penyebab Infeksi Saluran Kemih (ISK)
}

\author{
(Literature Review) \\ ${ }^{1}$ Erna Irawan, Universitas BSI Bandung, Erna.ewn@bsi.ac.id \\ ${ }^{2}$ Hilman Mulyana, Stikes Mitra Tasik, h_main@ymail.com
}

\begin{abstract}
ABSTRAK
Infeksi Saluran Kencing (ISK) menempati urutan kedua infeksi yang sering menyerang setelah infeksi saluran pernafasan dengan jumlah 8,3 juta pertahun. Terdapat banyak faktor yang menyebabkan terjadinya peningkatan angka kejadian ISK. Tujuan literature review ini adalah untuk menganalisis faktor-faktor yang mempengaruhi kejadian infeksi saluran kemih. Literature review dilakukan melalui jurnal yang berbasis elektronik yaitu database proquest dan google scholar. Artikel yang digunakan sesuai dengan kata kunci yaitu faktor-faktor yang berpengaruh terhadap terjadinya ISK (risk factor of urinary tract infection) dari tahun 2013-2018. Jenis penelitiannya adalah korelasi. Jumlah artikel yang ditemukan adalah 508 dan 10 artikel yang diambil sesuai dengan topik tersebut. Teknik penulisan menggunakan IMRAD. Faktor-faktor yang mempengaruhi angka kejadian infeksi saluran kemih (ISK) dapat dipengaruhi oleh bakteri (uropatogen) pseudomonas aeruginosa E.coli (UPEC) yang bermuatan $\mathrm{P}$ fimbriae, dan dapat dipengaruhi faktorpenyakit seperti penyakit HIV, DM tipe 2, inkontinensia urin serta dapat dipengaruhi oleh faktor lain seperti multi-drug resisten terhadap ISK, penggunaan popok yang lama pada anak, kebisaan hygiene yang kurang baik dan anak yang belum di sirkumsisi.
\end{abstract}

\section{ABSTRACT}

Urinary Tract Infection (UTI) ranks second infection that often attacks after respiratory tract infections with the amount of 8.3 million per year. There are many factors that cause an increase in the incidence of UTI. The purpose of this review literature is to analyze the factors that influence the incidence of urinary tract infections. Literature review is done through electronic journals based on proquest database and google scholar. Articles used in accordance with the keywords are factors that affect the 
occurrence of UTI (risk factor of urinary tract infection) from the year 2013-2018. The type of research is correlation. The number of articles found is 508 and 10 articles are taken according to the topic. Writing techniques using IMRAD. Factors affecting the rate of urinary tract infection (UTI) can be affected by the bacteria (uropatogen) pseudomonas aeruginosa E.coli (UPEC) containing $P$ fimbriae, and may be affected by factors such as HIV disease, type 2 diabetes, urinary incontinence and may be affected by other factors such as multi-drug resistant to UTI, the use of old diapers in children, poor hygiene and unopposed children.

\section{PENDAHULUAN}

Infeksi saluran kemih merupakan suatu infeksi baik pada saluran kemih atas dan atau bawah, yang mana jumlah bakteri $\geq 10^{5}$ koloni perunit bakteri permililiter $(\mathrm{CFU} / \mathrm{ml})$ dalam satu speimen urin (Bradley \& Colgan et al, 2005).

Menurut Rowe \& Juthani (2013) ISK adalah salah satu infeksi yang paling sering didiagnosis pada anak dan lansia. Angka kejadian ISK adalah 1:100 pertahun. Insiden ISK meningkat pada anak menurun pada umur dewasa dan meningkat lagi pada lansia. $>10 \%$ wanita yang > 65 tahun melaporkan mengalami ISK dalam 12 tahun terakhir. Jumlah ini meningkat hampir 30\% pada wanita >80 tahun. Menurut Sukandar (2006) ISK menempati urutan kedua infeksi yang sering menyerang setelah infeksi saluran pernafasan dengan jumlah 8,3 juta pertahun.
Infeksi saluran kemih di Indonesia dan prevalensinya tinggi. Jumlah penderita ISK di Indonesia adalah 95 kasus/ $10^{4}$ penduduk pertahunnya atau sekitar 180.000 kasus baru pertahun (Depkes, 2014).

Terdapat banyak faktor yang menyebabkan terjadinya peningkatan angka kejadian ISK. Bervariasinya penyebab ISK, luasnya spektrum organisme yang menjadi penyebab, serta sedikitnya uji klinis yang telah dilaksanakan, mempersulit penyusunan antimikroba pilihan yang dapat digunakan dalam terapi ISK (Shirby \& Soeliongan, 2013). Faktor risiko yang paling sering diidentifikasi adalah penggunaan antibiotik sebelumnya dan penggunaan katerisasi (Tenney et al, 2017). ISK adalah infeksi yang paling sering didapat di masyarakat dunia dan patogen yang paling umum adalah E. 
coli (Klapaczyńska (2018). Dengan banyaknya faktor ISK maka penelitian ini bertujuan literature review ini adalah untuk menganalisis faktor-faktor yang mempengaruhi kejadian infeksi saluran kemih

\section{LANDASAN TEORI}

Infeksi saluran kemih (ISK) adalah jenis infeksi nosokomial yang paling umum yang menyebabkan sekitar $40 \%$ dari semua infeksi per tahun. Selain itu, beberapa penelitian telah melaporkan bahwa sekitar $80 \%$ infeksi saluran kemih nosokomial terjadi setelah instrumentasi terutama kateterisasi (Darmadi, 2008).

Infeksi Saluran Kemih (ISK) merupakan penyakit infeksi yang sering ditemukan di praktik umum. Beberapa penelitian menunjukkan adanya faktor-faktor yang dapat menyebabkan terjadinya ISK seperti umur, jenis kelamin, berbaring lama, penggunaan obat immunosupresan dan steroid, pemasangan katerisasi, kebiasaan menahan kemih, kebersihan genitalia, dan faktor predisposisi lain (Sholihah, 2017)

Angka kejadian ISK meningkat pada pasien berumur 40 tahun ke atas dengan puncak tertinggi yaitu pada kelompok umur 50-59 tahun. Sebagian besar pasien ISK berjenis kelamin perempuan (Shirby $\&$ Soeliongan, 2013).

\section{METODELOGI}

Literature review dilakukan melalui jurnal yang berbasis elektronik yaitu database proquest \& google scholar. Artikel yang digunakan sesuai dengan kata kunci yaitu faktor-faktor yang berpengaruh terhadap terjadinya ISK (risk factor of urinary tract infection) dari tahun 2013-2018. Jenis penelitiannya adalah korelasi. Jumlah artikel yang ditemukan adalah 508 dan 10 artikel yang diambil sesuai dengan topik tersebut.

\section{HASIL}

Menurut Dawa et al (2014) melakukan penelitian kepada 57 pasien dengan kateter urin saat masuk rawat inap bedah dan ortopedi antara Mei dan Juni 2013. Peneliti juga mengumpulkan data dari masing-masing kasus pasien menggunakan daftar periksa yang meliputi: tanggal penyisipan kateter, tanggal pengangkatan, investigasi laboratorium yang relevan misalnya, hasil kultur urin jika tersedia. Sampel 
urin sama-sama diperoleh dari beberapa pasien untuk kultur. Hasil menunjukkan ISK lebih banyak pada pasien laki laki $(26,3 \%)$ dibandingkan dengan pasien perempuan $(19,3 \%),(15,7 \%)$ faktor usia mengalami penurunan $(11,5 \%)$ dari hasil 7 penelitian sebelumnya, $(50,9 \%)$ memiliki kantong drainase penuh. Pertumbuhan bakteri yang signifikan ditemukan pada 45,6\% (26) pasien dengan kateter urin dibandingkan dengan 54,4\% (31) dari pasien yang kultur urinnya tidak menghasilkan pertumbuhan organisme yang signifikan. Sekitar 84,2\% (48) pasien berada di kateter urin berdiam, 21,1\% (12) pasien pemasangan kateterisasi lebih dari sepuluh hari setelah pemasangan kateter dan kateterisasi jangka panjang dapat berrisiko signifikan infeksi saluran kemih. (84,7\%) gram negatif adalah patogen yang paling umum termasuk Pseudomonas aeruginosa, E. coli, Klebsiella spp dan Proteus spp.

Menurut Tenney et al (2017) tujuan dari penelitian ini adalah untuk mengumpulkan data yang diterbitkan saat ini untuk menentukan faktor risiko yang paling sering dan konsisten diidentifikasi untuk ISK. Database yang digunakan adalah PubMed, Embase, dan
Cochrane dari 1966 hingga Februari 2016 untuk artikel yang mengidentifikasi faktor risiko untuk MDR UTI. Didapatkan 25 penelitian termasuk 31.284 pasien dengan budaya positif memberikan bukti untuk 12 faktor risiko UTI MDR . Faktor risiko yang paling sering diidentifikasi adalah penggunaan antibiotik sebelumnya, sebagaimana dibuktikan dalam 16 dari 20 penelitian yang mengevaluasi faktor risiko ini. Rentang waktu yang digunakan untuk menentukan penggunaan antibiotik sebelumnya berkisar dari 2 hari hingga 365 hari. Faktor risiko lain dengan data pendukung terkuat adalah kateterisasi urin, rawat inap sebelumnya, dan rumah perawatan. 11 dari 14 penelitian yang menilai kateterisasi urin sebagai faktor risiko memberikan bukti bahwa kateter urin tidak hanya meningkatkan risiko pengembangan ISK, tetapi meningkatkan risiko ISK menjadi Multidrug resistant.

Menurut Janasiska et al (2017) yang melakukan penelitian dengan menggunakan desain penelitian cohort yang dikumpulkan menggunakan lembar observasi. Penelitian ini sudah dilakukan di RSU GMIM Pancaran Kasih Manado, pada Bulan September- Oktober 2017. 
Populasi pada penelitian ini adalah seluruh responden yang ada di UGD dan Ruang Rawat Inap RSU GMIM Pancaran Kasih Manado. Sampel yang digunakan yaitu sebanyak 30 orang. Hasil penelitian didapatkan bahwa sebagian besar responden berada pada rentang usia 26-30 tahun yaitu sebanyak 25 responden $(83 \%)$, sebagian besar pendidikan terakhir responden adalah diploma tiga (DIII) yaitu sebanyak 17 responden (53.5\%). Lama bekerja responden $\geq 1$ berjumlah 27 responden (90\%). Pada 30 kegiatan pemasangan kateter urine didapatkan sebagian besar pemasangan kateter urine tidak sesuai SPO yaitu sebanyak 23 responden (77\%) sedangkan pemasangan kateter urine sesuai SPO yaitu sebanyak 7 responden (23\%). Hasil analisis menunjukan bahwa dari 30 responden dengan pemasangan kateter urine tidak sesuai dan responden yang tidak terkena infeksi saluran kemih yaitu berjumlah 4 responden (17.4\%), sedangkan responden dengan pemasangan kateter urine tidak sesuai dan responden yang terkena infeksi saluran kemih yaitu berjumlah 19 responden $(82.6 \%), \quad$ sementara responden dengan pemasangan kateter urine yang sesuai dan responden yang tidak terkena infeksi saluran kemih yaitu berjumlah 6 responden $\quad(85.7 \%)$ sedangakan responden dengan pemasangan kateter urine yang sesuai dan responden yang tidak terkena infeksi saluran kemih yaitu berjumlah 1 responden $(14.3 \%)$. Terdapat hubungan antara pemasangan kateter dengan kejadian infeksi saluran kemih di RSU GMIM Pancaran Kasih Manado.

Menurut Shirby \& Soeliongan (2013) dengan sampel penelitian adalah semua pasiensuspect ISK yang akan dilakukan pemeriksaan kultur urin di Laboratorium Mikrobiologi RSUP Prof. dr. R. D. Kandou Manado periode November sampai Desember 2012. Bahan untuk sampel urin diambil dari Urin Porsi Tengah (midstream urine). Sebelumnya diberikan penjelasan mengenai cara pengambilan urin untuk menghindari kontaminasi. Kemudian dilakukan hitung bakteri. Jika jumlah bakteri >10per $\mathrm{ml}$ urin pemeriksaan dilanjutkan dengan isolasi dan identifikasi. Bakteri selanjutnya diinokulasi pada media isolasi dan diinkubasi pada suhu $37^{\circ} \mathrm{C}$ selama 24 jam. Kemudian dibuat pengecatan gram untuk mendapatkan sifat gram dari kuman yang ditemukan. Selanjutnya 
dilakukan identifikasi jenis bakteri penyebab ISK. Hasil penelitian menunjukkan 36 pasien dicurigai ISK dan hanya 30 pasien yang diperiksa urinnya. Dari 15 sampel tersebut ditemukan bahwa Escherichia colimerupakan mikro organisme tersering yang menyebabkan ISK yaitu sebanyak 5 kasus $(16,7 \%)$. Hal ini sesuai dengan hasil penelitian yang dilaporkan oleh Samirah, dkk. (2004) dan Mahesh et al. (2011) yang menemukan E. coli sebagai jenis bakteri penyebab ISK tersering. Saluran kemih merupakan tempat yang paling umum dari infeksi E. coli, dan lebih dari 90\% ISK tanpa komplikasi disebabkan infeksi E. Coli. Tingkat kekambuhan setelah infeksi E. coli pertama adalah $44 \%$ selama 12 bulan.

Menurut Wilke et al (2015) diabetes melitus tipe 2 (T2DM) terkait dengan tingkat peningkatan infeksi saluran kencing (ISK) (Chen, Jackson, \& Boyko, 2009; Fu et al, 2014;. Hill, Fayyad, \& Jones, 2008;. Muller et al, 2005; Yeshitela, Gebre-Selassie, \& Feleke, 2012). Penelitian kohort dilakukan berdasarkan pada kumpulan data yang di anonimkan dari data penyakit Jerman regional (2010-2012).
Kejadian ISK terutama diidentifikasi melalui diagnosis UTI rawat jalan / rawat inap yang diamati. Hasil menunjukkan jumlah kejadian ISK per 1000 pasien-tahun. Faktor yang paling penting yang terkait dengan risiko ISK adalah usia yang lebih tua (Hazard Ratio $(\mathrm{HR})=1,56-1,70$ untuk $>79$ tahun), jenis kelamin perempuan $(\mathrm{HR}=1,38$ 1,57), UTI dalam dua tahun sebelumnya $(\mathrm{HR}=2.77-5,94)$, jumlah penyakit penyerta yang diukur dengan $\mathrm{CCI}(\mathrm{HR}=$ 1,32-1,52 untuk CCI> 6) dan setidaknya satu cystoscopy pada tahun sebelumnya $(\mathrm{HR}=2,06-5,48)$. Selain itu, nilai-nilai HbA1c tinggi di tahun sebelumnya (HR $=1,29-1,4$ mengacu HbA1c $>9,5 \%$ ) dan fungsi ginjal yang buruk $(\mathrm{HR}=1,11$ 1,211 mengacu pada laju filtrasi glomerulus (GFR) $<60 \mathrm{ml} /$ menit) meningkatkan risiko ISK. Kesimpulannya, risiko kejadian ISK tinggi pada pasien DMT2. Pasien wanita yang lebih tua yang memiliki pengalaman ISK sebelumnya menghadapi risiko ISK di atas rata-rata, terutama jika faktor-faktor risiko ini terkait dengan kontrol glikemik yang buruk dan fungsi ginjal yang buruk

Menurut Klapaczyńska (2018) ISK adalah infeksi yang paling sering didapat 
di masyarakat dunia dan patogen yang paling umum adalah E. coli. Pasien HIV positif juga rentan terhadap infeksi saluran kemih. Insiden infeksi saluran kemih pada populasi HIV jelas terkait dengan infeksi dan fungsi kekebalan tubuh, ditentukan oleh limfosit jumlah sel CD4+. Sebagaimana ditegaskan oleh studi observasional kejadian berbagai infeksi bakteri pada pasien terinfeksi HIV, termasuk infeksi saluran kemih, berbanding terbalik dengan jumlah CD4 limfosit. Oleh karena itu tujuan dari penelitian ini adalah untuk menganalisis faktor yang terkait dengan kejadian dan spektrum patogen bakteri yang diidentifikasi dalam kelompok pasien yang diikuti di HIV Out-Patient Clinic di Warsawa. Database klinik dari Klinik Rawat Jalan HIV di Warsawa mengumpulkan semua informasi medis pada pasien yang secara rutin diikuti sejak 1994 hingga 2015. Kultur urin positif didefinisikan ketika menunjukkan jumlah koloni bakteri lebih besar dari atau sama dengan 103 unit pembentuk koloni per 1 organisme saluran kemih tipikal. Secara total 608 pasien dilakukan kultur urin, sebagian besar $432(71,1 \%)$ adalah laki-laki, 378 (62,2\%), 258 $(42,4 \%)$ terinfeksi melalui kontak homoseksual. Rata-rata jumlah CD4 + limfosit median adalah 385 (IQR: 204565) sel / 1 dan rata-rata sel CD4 nadir limfosit 197 (86-306) sel / 1. Seratus delapan belas pasien secara aktif terinfeksi HCV, sebagaimana didefinisikan oleh PCR real-time positif. Secara total $141 \quad(23,2 \%)$ pasien memiliki kultur urin positif, patogen bakteri yang paling umum adalah E.coli $(58,2 \%)$ dan E. faecalis $(12,8 \%)$. Pasien dengan infeksi saluran kemih lebih cenderung wanita $(51,8 \%$ vs $22,1 \%$, p $<0,0001)$, terinfeksi melalui selain mode homoseksual $(80,1 \%$ vs $50,7 \%, \quad$ p $<0,0001$ ), dengan jumlah CD4 nadir yang lebih rendah (139 vs 221 sel / 1, p $<0,0001$ ) dan RNA HIV awal yang lebih rendah (4,02 vs 4,35 log kopi / ml, p = 0,01) dan cenderung menjadi HCV RNA positif $(26,9 \%$ vs $49,2 \%, p=0,01)$. Dalam model regresi multivariat $(\mathrm{OR}=$ 2,10; [95\% CI: 1,24-3,56]), terinfeksi melalui selain mode homoseksual $(2,05$; [1,18-3,56]) dan jenis kelamin perempuan $\quad(2,14 ; \quad[1,33-3.44])$ meningkat dan jumlah nadir CD4 + menurun lebih tinggi $(0,92 ;[0,85-0,99])$ kemungkinan infeksi saluran kemih.

Menurut Girard \& Gaujard ( 2017) melakukan penelitian di unit geriatri 
rumah sakit universitas Lyon (Prancis), kelompok kerja multi-disiplin (grup NUTI) diimplementasikan dan dievaluasi tindakan korektif dari 2009 hingga 2015 sebanyak 4669 pasien dilibatkan: 1510 pada tahun 2009, 1547 pada tahun 2012, dan 1612 pada tahun 2015. Usia rata-rata pasien adalah 85,4 tahun (SD 7.2); perempuan lebih tua dari laki-laki (rata-rata: 86,4 versus 83,4 tahun $\mathrm{p}<0,001)$. Para pasien diikuti untuk total 83068 hari (rata-rata 17,8 hari). 4045 pasien tanpa kateter diikuti untuk total 73134 hari (rata-rata 18,1 hari). Jumlah total NUTI adalah 189 (4,0\% pasien), dan 59,8\% dari ini $(\mathrm{n}=$ 113) diamati di antara 4045 pasien tanpa kateter $(2,8 \%$ pasien $)$. ISK secara signifikan lebih sering terjadi pada pasien wanita, pasien imunosupresif, retensi akut, sisa post-void, riwayat infeksi saluran kemih dalam 6 bulan sebelumnya, dan pada pasien dengan ISK pada inklusi.

Menurut Reuven (2018) Faktor risiko yang berhubungan dengan perawatan didefinisikan sesuai dengan literatur. Ini termasuk jenis perawatan (perawatan akut, rehabilitasi, atau lama tinggal), jenis kateterisasi urin (berdiam, intermiten, atau supra-pubik), kehadiran nefrostomi, dan penggunaan kondom dan popok. Kateterisasi intermiten hanya dilakukan jika sebelum infeksi (kateterisasi sesekali untuk mikrobiologi pengujian dikecualikan). ISK secara signifikan lebih sering terjadi pada pasien wanita, pasien imunosupresif, retensi akut, sisa post-void, riwayat infeksi saluran kemih dalam 6 bulan sebelumnya, dan pada pasien dengan ISK pada inklusi.

Menurut Sholihah (2017) Infeksi Saluran Kemih (ISK) merupakan penyakit infeksi yang sering ditemukan di praktik umum. Beberapa penelitian menunjukkan adanya faktor-faktor yang dapat menyebabkan terjadinya ISK seperti umur, jenis kelamin, berbaring lama, penggunaan obat immunosupresan dan steroid, pemasangan katerisasi, kebiasaan menahan kemih, kebersihan genitalia, dan faktor predisposisi lain. Penelitian ini menggunakan desain potong-lintang. Teknik pengambilan sampel yaitu total sampling dengan jumlah responden sebesar 30 orang. Pengumpulan data menggunakan kuesioner dan hasil uji mikrobiologis. Responden terdiagnosis ISK sebanyak 23 orang $(76,7 \%)$. Hasil analisis bivariat menunjukkan bahwa tidak ada hubungan 
yang bermakna antara kejadian ISK4.2. PEMBAHASAN

dengan umur $(\mathrm{p}=1,000)$, jenis kelamin ( $\mathrm{p}=0,068$, kebiasaan menahan kemih $(\mathrm{p}=0,120)$, dan riwayat ISK sebelumnya $(\mathrm{p}=0,427)$. Kesimpulannya tidak ada variabel dalam penelitian ini yang berhubungan dengan kejadian ISK.

Menurut Luailiyatul Maknunah (2016) bertujuan menganalisis faktor risiko yang berhubungan dengan kejadian ISK pada anak di Poli Anak RSUD Blambangan Kabupaten Banyuwangi menggunakan pendekatan kasus kontrol (case control). Sampel dalam penelitian ini adalah pasien rawat jalan berusia 0-11 tahun di Poli Anak RSUD Blambangan Kabupaten Banyuwangi pada bulan JanuariSeptember 2015. Jumlah sampel penelitian ini sebanyak 134 responden (67 kontrol dan 67 kasus) dengan metode stratified random sampling. Hasil analisis bivariabel menggunakan uji chi-square dan uji cramer menunjukkan adanya hubungan yang signifikan antara kebersihan genitalia, frekuensi penggantian popok sekali pakai, durasi penggunaan popok sekali pakai dan kebiasaan menahan BAK dengan kejadian ISK ( $p$-value < 0,05).
A. Dari 10 penelitian didapatkan bahwa faktor resiko isk

disebabkan oleh :

1. Organisme gram negatif bakteri “ pseudomonas aeruginosa" adalah patogen yang paling umum yang bertanggung jawab untuk pengembangan infeksi saluran kemih diantara pasien kateter yang didapatkan dari pemasangan kateter dalam jangka panjang, serta bisa diakibatkan juga oleh hygine kateter, disfungsi bladder pada usia lanjut dan pemasangan kateter yang tidak sesuai dengan SOP.

2. Pola bakteri : Uropathogenic Escheria coli (UPEC) yang bermuatan $\mathrm{P}$ fimbriae agen penyebab sebagian besar ISK, termasuk sytitis, serta BPH.

\section{B. Menyatakan ISK terjadi} karena faktor pendukung (penyakit) :

1. Inkontensia urin : pemasangan Sling miduteral yang 
mengakibatkan terjadinya

ISK setelah 1 tahun tindakan

Sling-miduteral. Karena usia

lanjut yang mengakibatkan

menurunnya fungsi organ

kemih

2. Hiv : bakteri e coli (kontak homoseksual) dan dampak penyakit HIV

3. DM tipe 2 : karena kontrol glikemik yang buruk dan fungsi ginjal yang buruk serta riwayat sik sebelumnya

\section{Faktor lainnya :}

1. Isk dapat disebabkan akibat resisten terhadap berbagai obat antibiotik

(sulfamethoxazole-

trimetropim) dalam isk serta faktor lainnya misalnya : kateterisasi urin, rawat inap sebelumnya

2. (Menurut Luailiyatul

Makmunah (2016))

menyatakan bahwa infeksi saluran kemih anak diakibatkan sebagian besar pada anak laki-laki karena tidak disirkumsisi , kebiasaan membersihkan genetalia yang kurang baik, menggunakan popok sekali pakai dengan frekuensi penggantian popok sekali pakai <4 kali perhari dan durasi penggunaan popok yang lama, serta kebiasaan menahan BAK.

\subsection{KESIMPULAN}

Faktor-faktor yang mempengaruhi angka kejadian infeksi saluran kemih (ISK) dapat dipengaruhi oleh bakteri (uropatogen) pseudomonas aeruginosa E.coli(UPEC) yang bermuatan $P$ fimbriae, dan dapat dipengaruhi faktorpenyakit seperti penyakit HIV, DM tipe 2, inkontinensia urin serta dapat dipengaruhi oleh faktor lain seperti multi-drug resisten terhadap ISK, penggunaan popok yang lama pada anak, kebisaan hygiene yang kurang baik dan anak yang belum di sirkumsisi.

\section{REFERENSI}

- Dawa K.K. Rn, Rm, Bnsc.,dkk (2014). Assessment Of Risk Factors Influencing The Development Of 
Urinary Tract Infections Among

Catheterized Patients In University

Of Maiduguri Teaching Hospital (Umth). IOSR Journal of Nursing and Health Science (IOSRJNHS),64-71.

- Justin Tenney,.dkk (2017).Risk factors for aquiring multidrugresistant organisms in urinary tract infections: A systematic literature review. Saudi Pharmaceutical Journal,1-7.

- Nicolle LE, Bradley S, Colgan R et al (2005). Infectious Diseases Society of America guidelines for the diagnosis and treatment of asymptomatic bacteriuria in adults. Clin. Infect. Dis. 40(5), 643-654

- Shirby A. CH. Sumolang, dkk (2013). Pola Bakteri Pada Penderita Infeksi Saluran Kemih Di Blu Rsup Prof. Dr. R. D. Kandou Manado Jurnal e-Biomedik (eBM), Volume 1 No.1 Hal 597-601

- Janasiska Kausuhe,dkk (2017). Hubungan Pemasangan Kateter Urine Dengan Kejadian Infeksi Saluran Kemih Di Rsu GMIM Pancaran Kasih Manado. e-Journal Keperawatan (eKp) Volume 5 No. 2. Hal 1-7
- Skrzat-KlapaczynSka. dkk (2015). Factors associated with urinary tract infections among HIV-1 infected patient.Plos ONE 13(1): e0190564.https://doi.org/10.1371/jo urnal.pone.0190564. hal 1-5

- Thomas Wilke. dkk (2015). Epidemiology of urinary tract infections in type 2 diabetes mellitus patients: An analysis based on a large sample of 456,586 German T2DM patients. Else silvier Inc. All rights reserved. Hal 1016-1022

- Adi Y. Weintraub,dkk (2017). Prevalence and risk factors for urinary tract infection up to one year following midurethral sling incontinence surgery. European Journal of Obstetrics \& Gynecology and Reproductive Biology. Hal 146150.

- Raphaele Girard, MD,dkk(2017). Risk factors for urinary tract infections in geriatric hospitals. Journal of Hospital Infection. Hal 119

- Rowe, T. A., \& Juthani-Mehta, M. (2013). Urinary tract infection in older adults. Aging Health, 9(5), 519-528.

https://doi.org/10.2217/ahe.13.38 
- Luailiyatul Maknunah (2016) Faktor

Risiko Kejadian Infeksi Saluran Kemih Pada Anak Di Poli Anak Rsud Blambangan Kabupaten Banyuwangi

- Alfi Hidayatus Sholihah (2017) Analisis Faktor Risiko Kejadian
Infeksi Saluran Kemih (ISK) oleh bakteri uropatogen di Puskesmas Ciputat dan Pamulang

- Dr.umami Vidia. At a Glance Ilmu Bedah. Jakarta: Penerbit Erlangga. 2006. 